\title{
Effects of Fungicides, Essential Oils and Gamma Irradiated Bioagents on Chickpea Root Rot Caused by Sclerotium rolfsii
}

\author{
A. I. El-Batal ${ }^{\#}$, A. A., Ismail*, H. M. Mubark**, Y. A \\ Mahmoud** and R. M. Fathy \\ Drug Radiation Research Dept., National Centre for Radiation \\ Research and Technology (NSRRT),P. O. Box; 29 Nasr City, \\ Cairo, Egypt, "National Agricultural Centre, Dokki, Giza, \\ Egypt and ${ }^{* *}$ Faculty of Science Tanta University, Tanta, Egypt. \\ ${ }^{\#}$ E.mail; aelbatal2000@Gmail.com.
}

\begin{abstract}
C CLEROTIUM ROLFSII (S. rolfsii) causes root rot disease

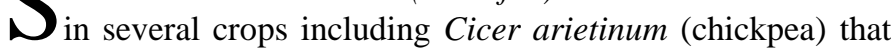
results in low yield. In vitro experiments on fungicides, vitavax and monceren $\mathrm{T}$, and essential oils, clove and mint oils, were conducted to control root rot disease of chickpea caused by $S$. rolfsii. The treatments resulted in $80 \%$ suppression of root rot disease. Gliocladium virens (G. virens) and Gliocladium deliquescens ( $G$. deliquescens) were effective as biocontrol agents against $S$. rolfsii. The results showed that these treatments greatly reduced the root rot disease in chickpea. In this study, the effect of gamma irradiation at doses $0,0.25,0.5,1.0,1.5,2.0,2.5$ and $3.0 \mathrm{kGy}$ on the pathogenecity of $G$. virens and $G$. deliquescens against $S$. rolfsii were investigated. The results revealed that gamma irradiation increased the pathogenecity of $G$. virens and $G$. deliquescens against $S$. rolfsii.

Keywords: Sclerotium rolfsii, chickpea, root rot, gamma radiation.
\end{abstract}

A wide variety of plants and trees are affected by root rot disease. These infections, most of which eventually prove fatal, consist of several different pathogens, all of which are fungi. Plants with root rot should be removed and destroyed. Chickpea is the most important commercial crop playing a key role in economic and social affairs in Egypt. It is an important food crop in many regions in the world. It is affected by various diseases. Damping- off and rootrot diseases are the most important diseases that affect plant stand causing great loss in chickpea crop, total nitrogen and protein contents in chickpea seeds. Chickpea is a good source of zinc, and protein. It is also very rich in dietary fibbers and hence is a healthy food source especially as a source of carbohydrates 
for persons with insulin sensitivity or diabetes. It is low in fat, and most of the fat content is mono unsaturated. $S$. rolfsii is a soil-borne plant pathogen of worldwide occurrence that infects more than 500 plant species (Aycock, 1966 and Punja, 1985). Most of the $S$. rolfsii caused diseases have been reported on dicotyledonous hosts, but several monocotyledonous species have also been infected (Aycock, 1966 and Mordue, 1974). Meristematic tissues of seedlings are susceptible to $S$. rolfsii, and the hyphyae growing either from infected seed or from soil invade all immature seedling tissues causing death prior to or just after emergence.

Herbicides, fungicides insecticides and plant growth regulators, form a group of agrochemicals that are available to protect crops and maintain their yield. In the initial phases of pathogenic attack, the pathogen might be an aggressive member of a complex that can initially elaborate "attacking mechanisms" to foster invasion of the host. In nature, essential oils play an important role in the protection of the plants as antibacterial, antiviral, or antifungal agent, as insecticides and act against herbivores by reducing their appetite for such plants (Ipek et al., 2005). Plant resistance provides an environmentally and economically appropriate means for disease control that can be easily included within an integrated disease management strategy. Antagonisms may operate by using the pathogen as a food source. If the pathogen is a fungus then the antagonist is a mycoparasite and usually possesses chitinase to breakdown the cell wall of the fungus. If the pathogen is an oomycete (e.g. Pythium or Phytophthora) then cellulase is needed. In general, microorganisms differ greatly in their sensitivity to irradiation. Different microorganisms have different degrees of radio- sensitivity when they are exposed to ionizing radiation. The inhibition of metabolic processes by radiation is associated with damage of the plasma membrane (James and Nasim, 1987). On the other hand, Khalaf (1993) investigated that gamma radiation decreased the antagonistic effect of Trichoderma lignorum (T. lignorum) in controlling damping-off bean caused by Rhizoctonia solani ( $R$. solani).

In the present study we aim to control root rot of chickpea caused by $S$. rolfsii by fungicides, essential oils and gamma irradiated bioagents in vitro and in vivo. These treatments have antifungal effect. So, they can be used to control chickpea root rot.

Egypt. J. Rad. Sci. Applic., Vol. 25, No. 1-2 (2012) 


\section{Materials and Methods}

\section{Control of the fungus}

Inhibitory effects of two fungicides namely vitavax and monceren $\mathrm{T}$ and two essential oils namely clove and mint oils were tested in vitro against the pathogenic fungus $S$. rolfsii. A laboratory study was performed to examine the sensitivity of both pathogenic and antagonistic fungi to the tested fungicides, and oils. After several preliminary experiments seven suitable concentrations of each fungicide and oil were chosen, as follows: 0.01, 0.1, 1.0, 5.0, 10, 25 and 50 ppm. The required concentrations were obtained by adding the appropriate amount of the stock solution to $100 \mathrm{ml}$ of autoclaved potato dextrose agar (PDA) medium which was then cooled to about $45^{\circ} \mathrm{C}$ (not solidified). Three petri dishes were used as replicates for each concentration whilst four plates were left without any treatment as control. After the medium solidified, each dish was inoculated centrally with a mycelial disk $(0.5 \mathrm{~cm}$ in diameter) taken from the fungal cultures of 3 days old. Plates were incubated at $28^{\circ} \mathrm{C}$ and colony diameters were measured until untreated control plates were fully covered by the fungus. Linear growth $(\mathrm{cm})$ was measured daily. The average of two perpendicular diameters was recorded. The percentage of inhibition (I \%) was calculated according to Topps and Wain (1957) equation as follows:

$$
\mathrm{I} \%=(\mathrm{A}-\mathrm{B}) / \mathrm{A} \times 100 .
$$

Where, I \%= Inhibition percentage. A= Mean diameter of growth in the control plates. $\mathrm{B}=$ Mean diameter of growth in treatment plates.

The median inhibition concentration $\left(\mathrm{IC}_{50}\right)$, the concentration of each treatment that is required to cause fungi toxic inhibition of the tested fungus by $50 \%$ in comparison with the control was determined.

\section{Antagonism between the pathogenic fungus and the antagonistic fungi}

Each petri dish containing $15 \mathrm{ml}$ of PDA medium was divided into two equal halves, the first half was inoculated with a disk $(0.5 \mathrm{~cm}$ in diameter) of the tested antagonistic fungus (T. hamatum/ G. deliquescens/ G. virens) and the second half was inoculated with a similar size disk of the pathogenic fungus $S$. rolfsii. Plates inoculated only with the pathogenic fungus acted as control. Each treatment was replicated four times. All petri dishes were incubated at 
$28^{\circ} \mathrm{C}$ and observed daily. After 3 days incubation, when the pathogenic fungus almost covered the surface of the medium in the control treatment, the percentage of inhibition (I \%) was calculated.

\section{Effect of gamma radiation on $G$. virens and G. deliquescence}

As shown before, the first half of each petri dish containing $15 \mathrm{ml}$ PDA medium was inoculated with $0.5 \mathrm{~cm}$ of the pathogenic fungus and the second half was inoculated with $G$. virens or $G$. deliquescence gamma irradiated at doses $0.25,0.5,1.0,1.5,2.0,2.5,3.0 \mathrm{kGy}$. Petri dishes were then incubated at $28^{\circ} \mathrm{C}$. The percentage of inhibition (I \%) was calculated. Irradiation process was carried out at (NCRRT). The irradiation facility was Gamma Chamber 4000- A India with radioactive source ${ }^{60} \mathrm{Co}$ delivering an average dose rate of $3.696 \mathrm{kGy} / \mathrm{h}$ at the time of experiments.

\section{Statistical analysis}

All the results were statistically analyzed. Analysis of variance and (Least significant difference) LSD was used if differences seemed to be found (Snedecor, 1967). Correlation for the control mortality was made by using Abbott`s formula.

\section{Results}

\section{Effect of the tested fungicides on the growth of S. rolfsii}

Vitavax was effective against the pathogenic fungus, $S$. rolfsii with $\mathrm{IC}_{50}$ (concentration giving $50 \%$ inhibition) for $S$. rolfsii was $0.9 \mathrm{ppm}$ as shown in Table 1. Monceren-T exerted toxic effect less than vitavax as its $\mathrm{IC}_{50}$ was $1.2 \mathrm{ppm}$.

TABLE 1. Effect of different concentrations of fungicides on the growth of $S$. rolfsii on PDA medium.

\begin{tabular}{|c|c|c|}
\hline \multirow{2}{*}{ Conc. of fungicides $(\mathrm{ppm})$} & \multicolumn{2}{|c|}{ Inhibition percentage (I \%) } \\
\cline { 2 - 3 } & Vitavax & Monceren -T \\
\hline 0.01 & 36.33 & 30.8 \\
\hline 0.1 & 42.44 & 38.32 \\
\hline 1 & 49.00 & 55.55 \\
\hline 5 & 63.33 & 59.11 \\
\hline 10 & 100 & 100 \\
\hline $\mathrm{IC}_{50}$ & 0.9 & 1.2 \\
\hline LSD & 6.1 & 3.62 \\
\hline
\end{tabular}

The mean difference is significant at the 0.05 level.

Egypt. J. Rad. Sci. Applic., Vol. 25, No. 1-2 (2012) 
Table 2. shows that the tested essential oils have toxic effect on the growth of $S$. rolfsii. Toxicity of the oils to the pathogenic fungus, $S$. rolfsii increased by the increasing concentration of the oil. Clove oil was more toxic to the pathogenic fungus $\left(\mathrm{IC}_{50}=5.4 \mathrm{ppm}\right)$ than mint oil $\left(\mathrm{IC}_{50}=6.1 \mathrm{ppm}\right)$.

TABLE 2. Effect of different concentrations of essential oils on the growth of $S$. rolfsii in vitro after three days.

\begin{tabular}{|c|c|c|}
\hline \multirow{2}{*}{ Conc. of essential oils $(\mathrm{ppm})$} & \multicolumn{2}{|c|}{ Inhibition percentage (I \%) } \\
\cline { 2 - 3 } & Clove oil & Mint oil \\
\hline 0.01 & 16.66 & 21.15 \\
\hline 0.1 & 33.63 & 29.68 \\
\hline 1 & 39.89 & 34.52 \\
\hline 5 & 51.36 & 53.25 \\
\hline 10 & 65.71 & 59.42 \\
\hline 25 & 73.83 & 81.60 \\
\hline 50 & 100 & 100 \\
\hline IC $_{50}$ & 5.4 & 6.1 \\
\hline LSD & 6.39 & 6.18 \\
\hline
\end{tabular}

The mean difference is significant at the 0.05 level.

The results in Table 3 indicates that $G$. deliquescens and G. virens have antagonistic effect against $S$. rolfsii with inhibition percentage of 61.11 and 67.78 respectively. However, $T$. hamatum has little antagonistic effect against S. rolfsii (18.89).

TABLE 3. Inhibitory percentage of $S$. rolfsii under the effect of antagonistic fungi in vitro.

\begin{tabular}{|c|c|}
\hline Antagonistic fungi & Inhibition percentage (I \%) of $\mathbf{S}$. rolfsii \\
\hline $\boldsymbol{T}$. hamatum & 18.89 \\
\hline G. deliquescens & 61.11 \\
\hline G. virens & 67.78 \\
\hline
\end{tabular}

The mean difference is significant at the 0.05 level.

\section{Effect of gamma irradiation on fungal antagonistic effect}

The results in Table 4 indicates that the antagonistic effect of $G$. virens and G. deliquescens against $S$. rolfsii increased by the increasing gamma irradiation doses up to $1.0 \mathrm{kGy}$ and $2.0 \mathrm{kGy}$, respectively and at which the highest antagonistic effect compared with control was observed. On the other hand, gamma radiation doses higher than $1.0 \mathrm{kGy}$ and $2.0 \mathrm{kGy}$ resulted the inferior of the antagonistic effect. 
TABLE 4. Effect of different doses of gamma irradiation on G. virens and G. deliquescens against $S$. rolfsii.

\begin{tabular}{|c|c|c|}
\hline \multirow{2}{*}{ Gamma irradiation $(\mathrm{kGy})$} & \multicolumn{2}{|c|}{ Inhibition percentage (I\%) } \\
\cline { 2 - 3 } & G. virens & G. deliquescens \\
\hline Unirradiated (control) & 50 & 48.86 \\
\hline 0.25 & 55.26 & 54.44 \\
\hline 0.5 & 58.8 & 57.78 \\
\hline 1.0 & 67.78 & 61.3 \\
\hline 1.5 & 56.51 & 64.4 \\
\hline 2.0 & 45.56 & 72.5 \\
\hline 2.5 & 31.21 & 51.1 \\
\hline 3.0 & 0.00 & 36.67 \\
\hline LSD & 1.08 & 2.68 \\
\hline
\end{tabular}

The mean difference is significant at the 0.05 level.

The results in Table 5. demonstrates that G. deliquescens gamma irradiated at $2.0 \mathrm{kGy}$ recorded the highest percentage of survival plants $(80 \%)$ followed by G. virens gamma irradiated at $1.0 \mathrm{kGy}(70 \%)$ compared to the infected control.

TABLE 5. Effect of gamma irradiation on $G$. virens and $G$. deliquescens against $S$. rolfsii in vivo.

\begin{tabular}{|c|c|c|}
\hline Treatments & Infected plants $(\%)$ & Survival plants $(\%)$ \\
\hline Healthy control & - & 100 \\
\hline Infected control & 50 & 50 \\
\hline Unirradiated $G V$ & 40 & 60 \\
\hline Unirradiated $G D$ & 50 & 50 \\
\hline Irradiated $G V(1.0 \mathrm{kGy})$ & 30 & 70 \\
\hline Irradiated $G D(2.0 \mathrm{kGy})$ & 20 & 80 \\
\hline LSD & 19.67 & 20 \\
\hline
\end{tabular}

The mean difference is significant at the 0.05 level.

\section{Discussion}

Root rot disease is considered as the most economically important and as the wide spread disease attacking chickpea plants will cause great loss in yield. For controlling root rot disease, effects of different substances on the causal organism are initially tested under laboratory conditions. By this method, a large number of substances can be screened and effective concentrations of the substances can be obtained. In the present work, we tested two fungicides, two essential oils and three bioagents also effects of gamma irradiation on the bioagents. The results could lead to developing an integrated disease control.

Egypt. J. Rad. Sci. Applic., Vol. 25, No. 1-2 (2012) 
Fungicides, vitavax and monceren-T at concentration of $10 \mathrm{ppm}$ completely inhibited the growth of $S$. rolfsii in vitro. Both of vitavax and monceren-T significantly inhibited sclerotial germination Mohamed et al. (2006). Our results are in agreement with report by Calleros et al. (2000) that revealed the efficacy of several fungicides (pencycuron, tolcoflos-methyl, fluazinam, azoxystrobin) and biocontrol agent $G$. virens against $S$. rolfsii in vitro. Only pencycuron and tolcoflos- methyl recorded $100 \%$ inhibition in vitro. Meena et al. (2004) showed that fungicides mancozeb and carbendazim caused $100 \%$ reduction in mycelial growth of Alternaria brassicae over control in vitro.

Both of the clove and mint oils at concentration of $50 \mathrm{ppm}$ completely inhibited the growth of $S$. rolfsii in vitro due to high amount of antimicrobial compounds that inhibit all the metabolic processes of the pathogenic fungus. Clove oil has high amount of the following antimicrobial compounds: eugenol, eugenol acetate, iso-eugenol and caryophyllene. On the other hand, mint oil contains menthol, menthone, 1,8-cineole, methyl acetate, metho furan, isomenthone, limonene, b-pinene, a-pinene, germacrene-d, trans, sabinene hydrate and pulegone.

Kandhari and Singh (2000) found that complete inhibition of $R$. solani was observed at $100 \mathrm{ppm}$ of environmental friendly plant, Ocimum basilicum. Tullio et al. (2007) determined the activity of some essential oils (thyme red, fennel, clove, pine, sage, lemon balm and lavender) against clinical and environmental fungal strains in vitro. Also, Zabka et al. (2009) found that essential oils from 25 species of medicinal plants inhibit growth of Fusarium oxysporum, F. verticillioides, Penicillium expansum, P. brevicompactum, Aspergillus flavus and A. fumigatus. The superior antifungal activity was in the case of Pimenta dioica.

G. deliquescens and G. virens antagonized the growth of $S$. rolfsii in vitro after 3 days as it prevented the formation of sclerotia and inhibited the different stages in sclerotial formation. Our results are in agreement with those obtained by Papavizas (1990) who reported that G. virens reduced germination and infectivity of sclerotia of $S$. rolfsii.

Errakhi et al. (2009) reported that actinomycetes can reduce in vivo the incidence of root rot induced by $S$. rolfsii on sugar beet due to their ability to inhibit sclerotial germination and hyphal growth of S. roflsii. Also, Gaur and 
Sharma (2010) reported that $T$. viride and $T$. harzianum effectively inhibited the growth of dry root rot pathogen, R. bataticola of cotton by 76.53 and $72.78 \%$, respectively.

In the present work, the results showed that due to the increased viability of G. virens and G. deliquescence by increasing the dose of gamma irradiation to $1.0 \mathrm{kGy}$ and $2.0 \mathrm{kGy}$ respectively, the antagonistic activity as a biological control against $S$. rolfsii also increased. These results were supported by the experiment conducted in the green house conditions where soil treated with the gamma irradiated bioagents increased the percentage of plant survival compared with unirradiated (control). Several researchers reported that gamma irradiation could enhance mould growth and enzyme activity (Applegate and Chipley, 1973, El-Batal et al., 2000, El-Batal et al., 2010, El-Batal and Abo State, 2006, El-Batal and Khalaf, 2002 and El-Batal, 1996).

\section{References}

Applegate, K. L. and Chipley, J. R. (1973) Effect of gamma irradiation on aflatoxin B1 and B2 production by Aspergillus flavus. Mycolog., 66, 436.

Aycock, R. (1966) Stem rot and other diseases caused by Sclerotium rolfsii. N.C State Univ. Tech. Bull., 174, 202.

Calleros, G. V., Portugal, O. and Carling, D. E. (2000) Anastomosis groups of Rhizoctonia solani on potato in central Mexico and potential for biological and chemical control. Am. J. Potato Res., 77, 219.

El-Batal A. I., Amin, M. A., Ali A. E. and El-Attar, N. (2010) Characterization of immobilization inulinase from gamma irradiated Penicillium chrysogenum strain. Egypt. J. Biotech., 36, 166.

El-Batal, A. I. and Abo-State, M. A. (2006) Production of cellulases, xylanase, and alpha amylase by Bacillus sp. And their mixed cultures with Candida tropicalis and Rhodotorula glutinis under solid state fermentation. Egypt. J. Rad. Sci. Applic., 19, 139.

El Batal, A. I and Khalaf, S. A. (2002) Production of pectinases by gamma irradiated interspecific hybrids of Aspergillus sp. using agro-industrial wastes. Egypt. J. Biotechnol., 12, 92.

El Batal, A. I (1996) Bioconversion of sugarcane molasses into glutamic acid by gamma irradiated Corynebacterium glutamicum. Arab. J. Nuc. Sci. Applic., 29, 233.

El-Batal, A. I., Abo-State, M. A. and Shihab, A. (2000) Phenylalanine ammonia lyase production by gamma irradiated and analoge resistant mutants of Rhodotorula glutinis. Acta Microbiol. Polonica, 49, 51.

Egypt. J. Rad. Sci. Applic., Vol. 25, No. 1-2 (2012) 
Errakhi, R., Lebrihi, A. and Barakate, M. (2009) In vitro and in vivo antagonism of actinomycetes isolated from Moroccan rhizospherical soils against Sclerotium rolfsii: a causal agent of root rot on sugar beet (Beta vulgaris L.). J. Appl. Microbiol., 107, 81.

Gaur, R. B. and Sharma, R. N. (2010) Biocontrol of root rot in cotton and compatibility of potential bioagents with fungicides. Ind. J. Plant Protec., 38, 176.

Ipek, E., Zeytinoglu, H., Okay, S., Tuylu, B. A., Kurkcuoglu, M. and Husnu Can Baser, K. (2005) Genotoxicity and antigenotoxicity of Origanum oil and carvacrol evaluated by Ames Salmonella/ microsomal test. Food Chem., 93, 551.

James, A. P. and Nasim, A. (1987) Effects of radiation on Yeast. In "The Yeasts", Vol. 2 (Rose, A.H. and Harrison, J.S. ed.) Academic Press, Inc. pp. 73-97.

Kandhari, J. and Singh, R. (2000) Efficacy of different extracts of certain indigenous plants against sheath blight pathogen of rice. J. Mycopathol. Res., 38, 125.

Khalaf, M. A. (1993) Effect of ionizing radiation and biological control on certain plant diseases. M. Sc. Fac.Sci. Zagazig Univ., Egypt.

Meena, P. D., Meena, R. L., Chattopadhyay, C. and Kumar, A. (2004) Identification of critical stage for disease development and biocontrol of Alternaria Blight of Indian Mustard (Brassica juncea). J. Phytopathol., 152, 204.

Mohamed, I. A., Bauiomy, M. A. and Ibrahim, A. S. (2006) Efficacy of different natural products as safe management of guar damping-off disease in Egypt. Egypt. J. Phytopathol., 34, 1.

Mordue, J. E. M. (1974) Corticium rolfsii. CMI Descriptions of Pathogenic Fungi and Bacteria. N0.410.

Papavizas, G. C. (1990) Influence of Gliocladium virens on germination and infectivity of sclerotia of Sclerotium rolfsii. Phytopathology, 80, 627.

Punja, Z. K. (1985) The biology, ecology and control of Sclerotium rolfsii. Annual Rev. Phytopathol., 23, 97.

Snedecor, G. W. (1967) Statistical methods 6th. Ed., Ames, Lowa, U.S.A. Iowa State Univ; Press.

Topps, J. H. and Wain, R. L. (1957) Investigation of fungicides. III. The fungitoxicity of 3-ans 5-alkyl salicylanilide and P-chloronilines. Ann. Appl. Biol., 45, 506.

Tullio, V., Nostro, A., Mandras, N., Dugo, P., Banche, G., Cannatelli, M. A., Cuffini, A. M., Alonzo, V. and Carlone, N. A. (2007) Antifungal activity of essential oils against filamentous fungi determined by broth micro dilution and vapor contact methods. J. Appl. Microbi., 102, 1544.

Zabka, M., Pavelaa, R. and Slezakovaa, L. (2009) Antifungal effect of Pimenta dioica essential oil against dangerous pathogenic and toxinogenic fungi. Indust. Crop. Product., 30, 250.

Received: 19/09/2012;

accepted: 05/12/2012.

Egypt. J. Rad. Sci. Applic., Vol. 25, No. 1-2 (2012) 


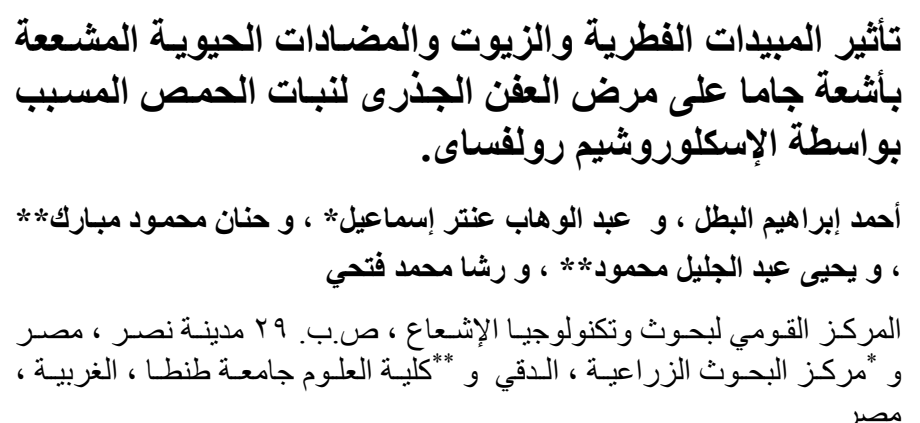

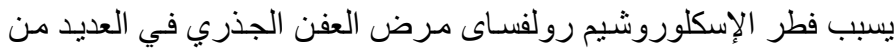

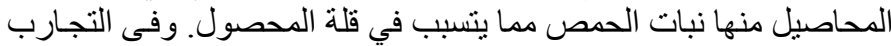

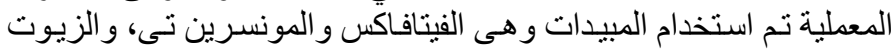

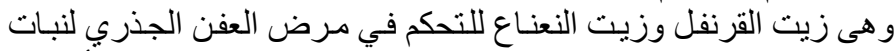

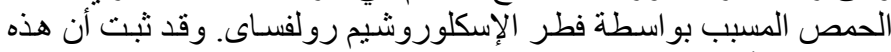

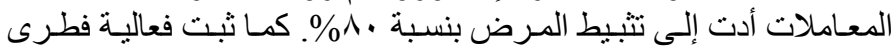

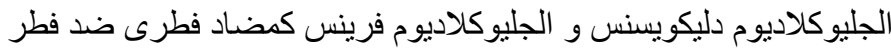

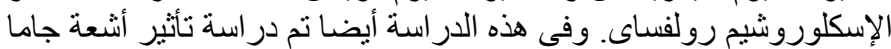

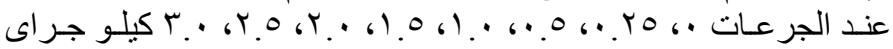

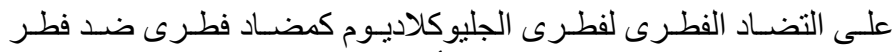

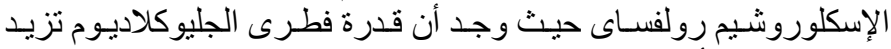

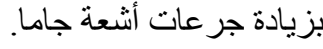

Egypt. J. Rad. Sci. Applic., Vol. 25, No. 1-2 (2012) 